\title{
Survival Patterns of Children with Rheumatic Heart Disease
}

\author{
Sudigdo Sastroasmoro, Bambang Madiyono, Ismet N Oesman, Sukman Tulus Putra, Najib Advani
}

\begin{abstract}
Abstrak
Makalah ini melaporkan hasil analisis kesintasan (survival analy'ses) pasien penyakit jantung reumatik yang berobat di Bagian Ilmu Kesehatan Anak Fakultas Kedokteran Universitas Indonesia - Rumah Sakit Dr. Cipto Mangunkusumo, Jakarta, antara Januari 1983 sampai Desember 1992. Dari 359 pasien yang dapat dianalisis, pada akhir pengamatan, jakni akhir bulan ke-120, 69,1\% pasien masih hidup. Perbandingan kurva kesintasan berdasarkan beberapa karakteristik memperlihatkan bahwa usia pada saat diagnosis dan jumlah katup yang terlibat berperan dalam prognosis, sedangkan jenis kelamin, pendidikan orangtua, dan status gizi tidak berhubungan dengan prognosis. Kesimpulan yang sama diperoleh bila dilakukan analisis univariat maupun multivariat terhadap 177 pasien yang telah diikuti selama 5 tahun atau lebih.
\end{abstract}

\begin{abstract}
We examined the survival curves of patients with established rheumatic heart disease treated at the Division of Cardiology, Department of Child Health, Faculty of Medicine University of Indonesia Cipto Mangunkusumo Hospital, Jakarta during the period of January 1983 until December 1992. There were 359 patients available for analysis. At the end of the 120-month observation, $69.1 \%$ patients were still alive. Comparisons of several curves based on certain characteristics showed that age at the time of diagnosis and the number of valves involved were associated with survival, while sex, parental education, or nutritional status were not. Closer examination of 177 patients who had completed 5 years of follow-up, both using univariate and multivariate analyses (logistic regression analysis) confirmed the results of survival analyses. We conclude that age at the time of diagnosis and the number of valvar involvement are strong determinants for the prognosis of children with rheumatic heart disease.
\end{abstract}

Key words: survival analysis, rheumatic heart disease, risk factors, prognosis.

Rheumatic fever is commonly considered as 'social disease'. The disease has rarely been found in industrial countries, but it is still prevalent in many developing countries ${ }^{1-5}$ including Indonesia. In some situations, however, rheumatic fever may cause resurgence in certain parts of some industrial countries ${ }^{6}$ indicating that this disease needs continuous attention. In the last 10 years, admission of children with rheumatic fever and rheumatic heart disease to our Department has been steady, i.e., approximately 50-80 patients per year. It has been our observation that the addition of several hospitals in Jakarta which care for pediatric cardiac cases, including patients with rheumatic heart disease, has not reduced the number of

\footnotetext{
* Department of Child Health, Medical School University of Indonesia, Jakarta
}

patients admitted to the Department of Child Health, Faculty of Medicine University of Indonesia Cipto Mangunkusumo Hospital, Jakarta.

It is noted that the majority of rheumatic patients in developing countries do not comply the proposed secondary prophylaxis, i.e., monthly administration of intramuscular benzathine penicillin. This would place the patients to the danger of recurrent attacks of acute rheumatic fever, which may result in further damage of the cardiac tissues, especially in those who have cardiac involvement on the previous attack. ${ }^{7}$ In contrast, many studies have indicated that the morbidity and mortality rates of patients with rheumatic heart disease, as a sequel of acute rheumatic fever, have decreased considerably if secondary chemoprophylaxis is given regularly and adequately. ${ }^{7}$ To the best of our knowledge there has been no study that analyzes the outcome of patients with rheumatic heart disease in the Indonesian medical literature. This study was 
aimed to describe and analyze the survival patterns of such patients, and determine some factors associated with the outcome.

\section{METHODS}

Records of all cardiac patients admitted to the Department of Child Health, and attendants of the Outpatient Clinic of the Division of Cardiology, Department of Child Health, Cipto Mangunkusumo Hospital were available in our database record. These served as a data base for our study. We collected records of patients with the diagnosis of acute rheumatic heart disease treated during the last 10 years (from January 1, 1983 up to December 31, 1992). Only patients living in Jakarta Municipality and its surrounding area (Bogor, Bekasi, and Tangerang Districts) were included in this study.

\section{Patient diagnosis and management}

The diagnosis of acute rheumatic fever was established either using revised or modified Jones criteria. ${ }^{8}$ Patients with the diagnosis of acute rheumatic fever were hospitalized for several weeks, and then were followed in the Outpatients Clinic. Monthly administration of benzathine penicillin were proposed for all patients. In every visit they were watched for the possibility of recurrent attacks or the development or progression of cardiac involvement.

Patients who had cardiovascular sequelae, either immediately following acute attack or evident later on, were classified as patients with rheumatic heart disease. Patient who were referred for the management of established rheumatic heart disease were generally not hospitalized, unless they are severely distressed or the possibility of a new acute rheumatic attack could not be excluded. They were also managed on OPD basis, with the administration of monthly (or every 3 weeks for severe cases) benzathine penicillin. Patients with frank or subtle congestive heart failure, as usually indicated by the presence of decrease exercise tolerance, were given anticongestants, mainly digitalis, diuretics, and in some cases, vasodilators.

The diagnosis of valvar abnormality was based on clinical findings 9,10 and was subsequently supported by other non-invasive diagnostic methods, i.e., chest $\mathrm{X}$-ray, electrocardiography, and echocardiography; the latter has been routinely performed since 1986 in every patient, new or old, with suspected or proved cardiovascular problem. Criteria for clinical and echocardiographic and Doppler study were described elsewhere. ${ }^{10-12}$

\section{Data collection}

For the purpose of the study the following information from each patient was collected : sex, date of diagnosis, age at diagnosis, parental education, number of valvar involvements, nutritional status at the time of diagnosis, date of loss to follow up, and date of death. With regard to patient's survival status, the following steps were performed:

1. From January 1993 to April 1993, all registered patients who made follow up visit to the OPD were identified; they were included in the survivor (or event free) group.

2. To those who did not show up in the OPD during that 4-month period, a letter containing a simple questionnaire was sent; only important information was asked for (last visit to the hospital, and survival status, including date of death). To those who did not respond to the first letter, a second letter was sent. If both letters were not responded in 2 months, 2 field workers made a home visit asking for the necessary information. If the patient's address was not found, then he or she was labelled as loss to follow-up.

Patients with rheumatic heart disease were grouped according to their age at the time of diagnosis into those who were less than 8 years and those who were 8 years or older. The socio-economic status was arbitrarily grouped according to the parental educational level, i.e. by averaging mother's and father's formal education, into those with 9 years or more, or those with less than 9 years of formal schooling. The patient's nutritional status was assessed by using the simplified classification of Wellcome Trust Party, as follows: well-nourished (body weight was $80 \%$ or more), undernourished (body weight was 60-80\% without the presence of edema), and malnourished (body weight was $60-80 \%$ with edema, or less than $60 \%$ ) of the reference curve. Fiftieth percentile of NCHS body weight for age curves were used as reference. The cardiac involvement was grouped into those with only 1 valve, and those with more than 1 valvar involvement, regardless of the severity of the involvements. 


\section{Statistical analyses}

The overall survival curve was constructed using Cuttler-Ederer method. Similar survival curves were also constructed after grouping the patients according to sex (male or female), age group at the time of diagnosis ( 8 years or older, or less than 8 years), number of valves involved ( 1 or more than 1 valvar involvement), nutritional status (well-nourished, undernourished/ malnourished), and parental educational status ( 9 years or more, or less than 9 years of formal schooling). For each pair of grouping a hypothesis testing was carried out by using log-rank statistical test. The survival analyses were performed by using True-Epistat statistical program.

Patients who had been followed-up for 5 years, i.e., those who had been diagnosed between January 1, 1983 through December 31, 1987, were analyzed separately. For this group of patients univariate analyses were performed using $\mathrm{x}^{2}$ for difference between 2 independent proportions, and the Odds ratios were calculated. We also supplied 95 confidence intervals wherever appropriate, and used $p<0.05$ for the level of significance. A logistic regression analysis by using SPSS-PC was performed for such patients, to determine the role of several risk factors on survival.

\section{RESULTS}

The total number of patients with the diagnosis of acute rheumatic fever or rheumatic heart disease during the 10-year period (January 1, 1983 to December 31, 1992) was 547. Details of the diagnosis and management of the patients have been described elsewhere. ${ }^{13}$ For this particular study 32 patients were excluded because they lived outside Jakarta Municipality and surroundings. Of the remaining 515 patients, 156 were free from cardiac involvement; they were not considered for further analysis. Therefore a total of 359 patients were left for survival analysis.

The clinical and demographic characteristics of the 359 patients at the time of diagnosis are depicted in Table 1. The distribution of valvar involvement is depicted in Table 2 which shows that mitral valve was the most commonly valve involved, followed by aortic valve. Tricuspid valve was only affected in small number of patients; we did not diagnose pulmonic abnormality in any of our patients.
Table 1. Characteristics of 359 patients with the diagnosis of rheumatic heart disease (January 1983 - December 1992)

\begin{tabular}{|c|c|c|}
\hline \multicolumn{3}{|l|}{ Sex } \\
\hline male & & 171 \\
\hline female & & 188 \\
\hline \multicolumn{3}{|l|}{ Age in months, mean (SD): } \\
\hline male & 121.4 & $(34.3)$ \\
\hline female & 104.2 & $(28.9)$ \\
\hline all patients & 112.3 & $(22.4)$ \\
\hline \multicolumn{3}{|l|}{ Age group : } \\
\hline$<8$ years & & 71 \\
\hline 8 years or more & & 288 \\
\hline \multicolumn{3}{|l|}{ Valvar involvement : } \\
\hline 1 valve & & 281 \\
\hline$>1$ valves & & 78 \\
\hline \multicolumn{3}{|l|}{ Parental educational level : } \\
\hline$<9$ yrs schooling & & 204 \\
\hline $\begin{array}{l}9 \text { yrs schooling } \\
\text { or more }\end{array}$ & & 155 \\
\hline \multicolumn{3}{|l|}{ Nutritional status : } \\
\hline well-nourished & & 163 \\
\hline under-nourished & & 119 \\
\hline malnourished & & 77 \\
\hline
\end{tabular}

Table 2. Valvar involvement in 359 patients with rheumatic heart disease

\begin{tabular}{|c|c|c|}
\hline Diagnosis & No. of patients & Percent \\
\hline Isolated mitral regurgitation & 234 & 65.2 \\
\hline $\begin{array}{l}\text { Mitral regurgitation + mitral } \\
\text { stenosis }\end{array}$ & 54 & 15.0 \\
\hline $\begin{array}{l}\text { Mitral regurgitation + aortic } \\
\text { regurgitation }\end{array}$ & 18 & 5.0 \\
\hline $\begin{array}{l}\text { Mitral regurgitation + tricuspid } \\
\text { regurgitation }\end{array}$ & 6 & 1.7 \\
\hline Isolated mitral stenosis & 34 & 9.5 \\
\hline Isolated aortic regurgitation & 13 & 3.6 \\
\hline
\end{tabular}

\section{Data on survival status}

From January 1, 1993 to April 30, 1993, 129 out of 359 patients with rheumatic heart disease whose diagnosis had been established earlier made their follow-up visit to the OPD. Twenty four patients with rheumatic heart disease were known to have died in our hospital, at home, or in other hospitals. A letter containing a simplified questionnaire was sent to 216 patients 
whose information was not available; the response rate of the first letter was reasonably high, i.e., 122 $(56.5 \%)$. When the second letter was sent to those who had not responded, 18 more responses were obtained. The remaining 76 patients whose survival status were not available were visited by 2 field workers, and it was found that $\mathbf{4 2}$ were loss to follow up. The final status of patients' survival data on December 31, 1992 was as follows: alive 259 patients, dead 58 patients, and losses to follow up 42 patients. See Table 3.

Table 3. Survival status of patients with rheumatic heart disease

\begin{tabular}{lcccc}
\hline & Alive & $\begin{array}{c}\text { Dead } \\
\end{array}$ & $\begin{array}{l}\text { Losses to } \\
\text { follow up }\end{array}$ & Total \\
\hline $\begin{array}{l}\text { Seen in the OPD during the } \\
\text { period of January-April 1993 }\end{array}$ & 119 & - & - & 119 \\
$\begin{array}{l}\text { Known to have died } \\
\text { before December 31, } 1992\end{array}$ & - & 24 & - & 24 \\
$\begin{array}{l}\text { Responded first letter } \\
\text { Responded second letter }\end{array}$ & 92 & 30 & - & 122 \\
$\begin{array}{l}\text { Visited at home } \\
\text { Loss to follow up }\end{array}$ & 34 & 4 & - & 18 \\
\hline & - & - & 42 & 42 \\
& 259 & 58 & 42 & 359 \\
\hline
\end{tabular}

\section{SURVIVAL ANALYSIS}

The overall 10-year survival curve of 359 patients with rheumatic heart disease is depicted in Figure 1. The survival proportion at the end of the 120 -month observation was $69.1 \%$. When the survival curves of male and female patients (female $=188$, male $=171$ ) were compared, there was no significant difference of both groups $(p=0.089)$ (Figure 2). Similar results were also seen when the patients were grouped according to parental educational level ( 9 years, 204; 9 years or more, 155; $p=0.092$, Figure 3). However, when the patients were grouped according to their age at the time of diagnosis, it is obvious that more patients aged less than 8 years died within 10 years after diagnosis than those aged 8 years or older ( $p=0.046$, Figure 4$)$. More strikingly, the mortality of patients who had more than 1 valvar involvement was significantly higher than those who only had 1 valvar involvement $(p=0.002$, Figure 5). No apparent significant difference was found when the survival curve was constructed according to the nutritional status (well-noushed or undernourished/malnourished). See Figure 6.

\section{Risk factors for non-survivals}

There were 202 patients with rheumatic heart disease diagnosed between January 1, 1983 to December 31, 1987. Of those, only 177 have complete information regarding survival. They were selected to enable us to analyze risk factors for death in rheumatic patients who were followed-up for the same period of time ( 5 years). During the 5-year period 32 of them died. They were analyzed by univariate as well as multivariate techniques for the following variables: sex, valvar involvement, age group at the time of diagnosis, parental education, and nutritional status.

\section{Univariate analyses}

The results of univariate analyses of the survivors and who died are depicted in Table 3. The table provides $p$ value of each analysis with its corresponding Odds Ratio (OR) and its $95 \%$ confidence interval. It appears that sex did not associate with survival, neither did parental educational level and nutritional status at the time of diagnosis. However, when the patients were grouped into those with 1 or more than 1 valvar involvement, a significant difference was obtained. Similar results were also obtained when the patients were compared according to their age group at the time of diagnosis.

\section{Multivariate analysis}

Logistic regression was applied using survival as dependent variable and sex, age group, valvular involvement, parental educational level, and nutritional status as independent variables. The results of this analysis are depicted in Table 4, which confirm the results of multivariate analyses, i.e., age group and valvar involvement were significant factors for survival, while sex, educational level, or nutritional status were not.

\section{DISCUSSION}

Our data confirmed previous reports and observations that cardiac involvement is the most frequent complication in rheumatic fever in developing countries. While in industrial countries arthritis is generally the most common manifestation of acute rheumatic fever, in developing countries carditis is the most frequently found manifestation. ${ }^{10}$ Consequently patients with cardiac sequelae in this series outnumbered patients without cardiac involvement. Table 1 also shows that there was apparently no difference between sex prevalence in rheumatic heart disease, but patients 


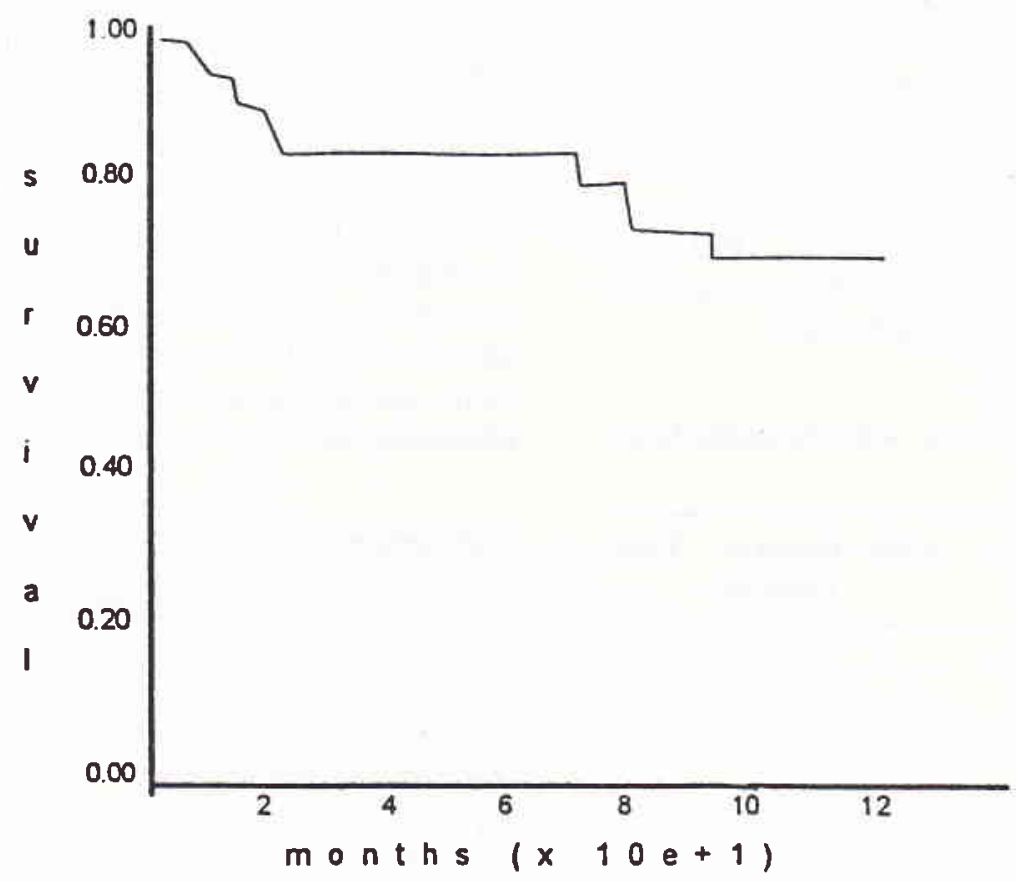

Figure 1. Overall 10-year survival curve of 359 patients with rheumatic heart disease

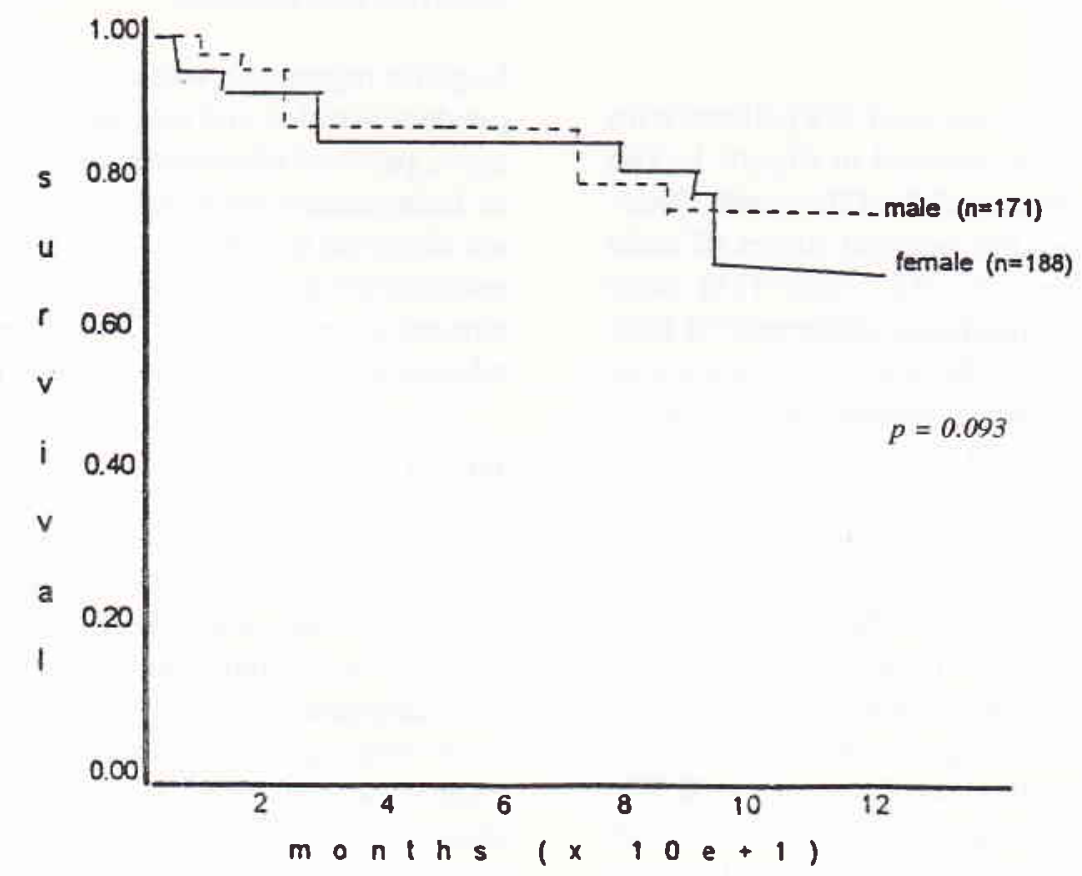

Figure 2. Comparison of 10-year survival curves of patients with rheumatic heart disease according to sex 


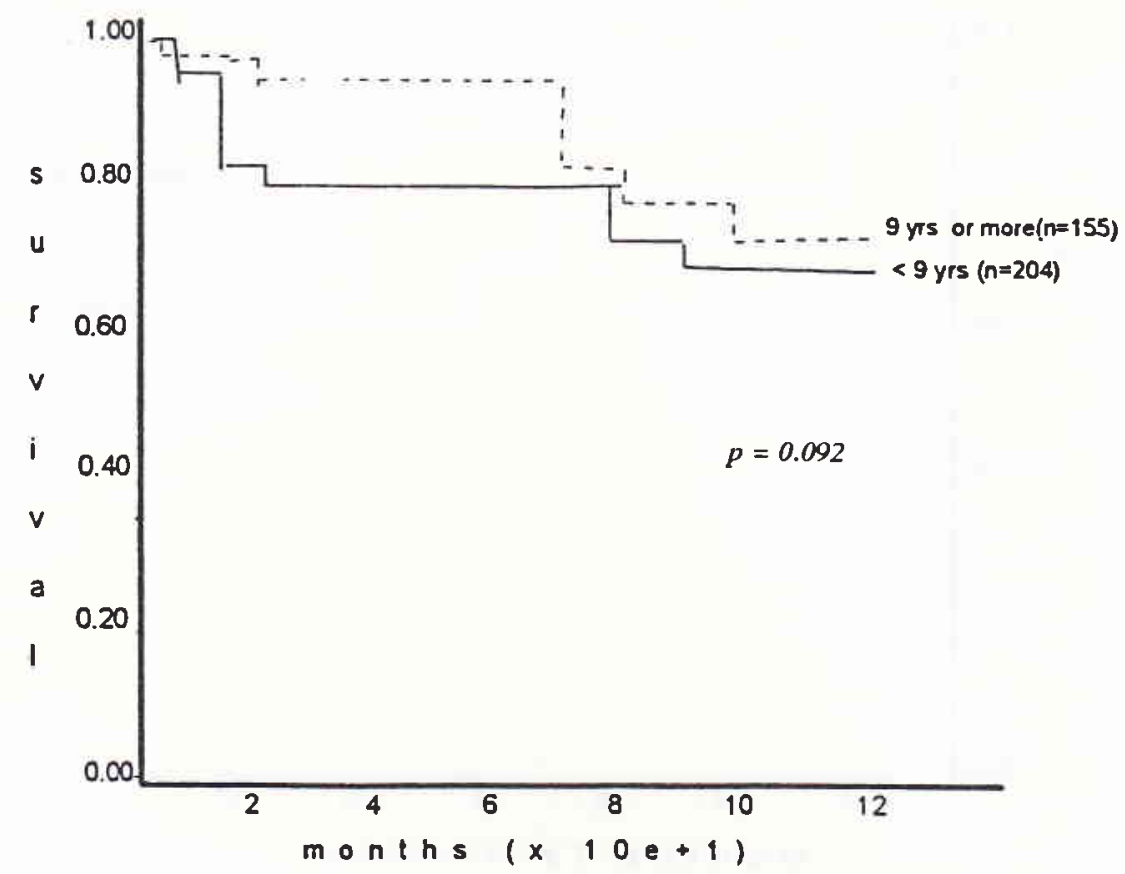

Figure 3. Comparison of 10-year survival curves of patients with rheumatic hart disease according to parental educational level

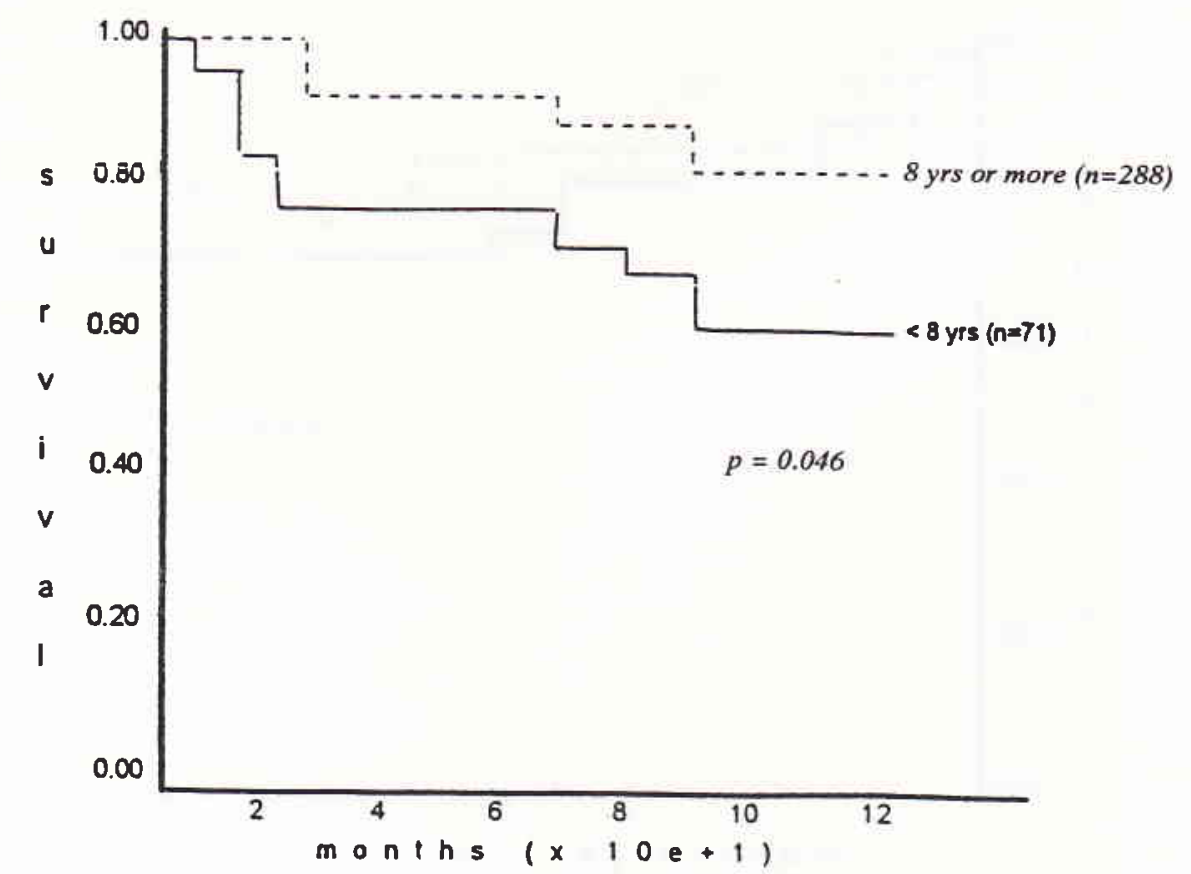

Figure 4. Comparison of 10-year survival curve of patients with rheumatic heart disease according to age group at the time of diagnosis 


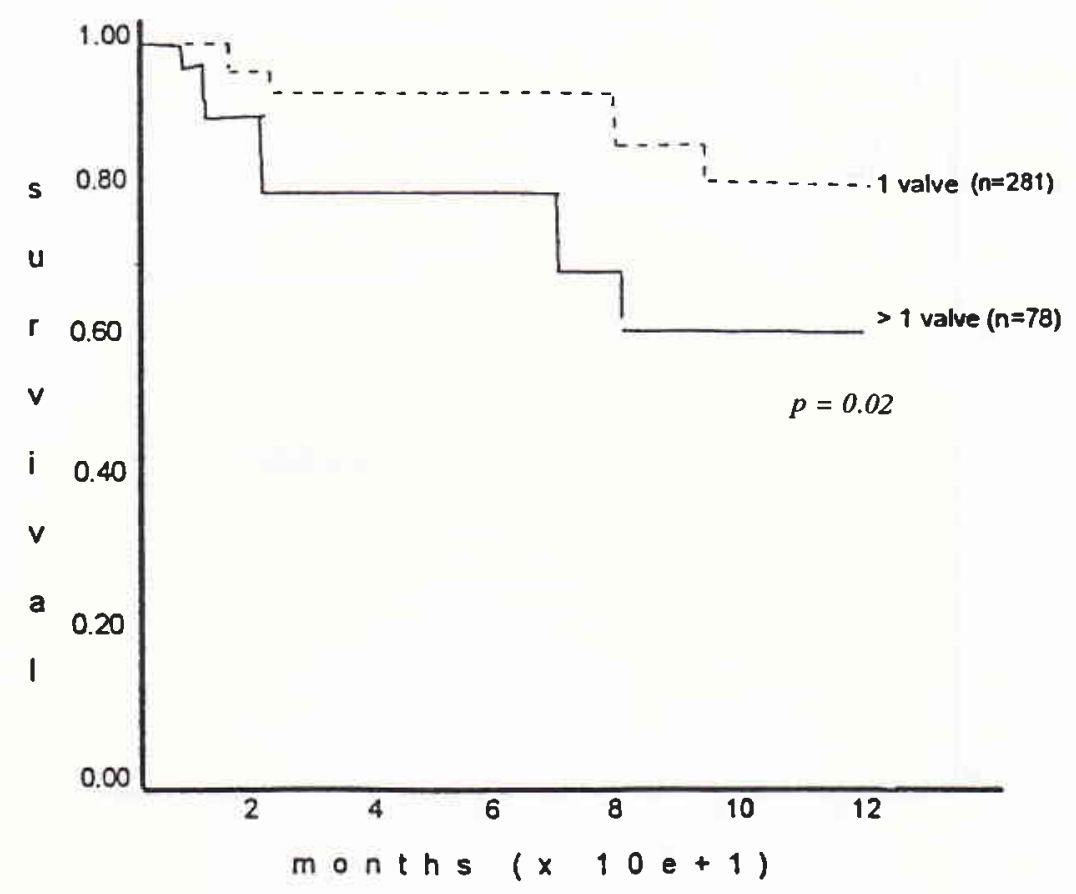

Figure 5. Comparison of survival curveof patient with rheumatic heart disease according to the number of valves involved

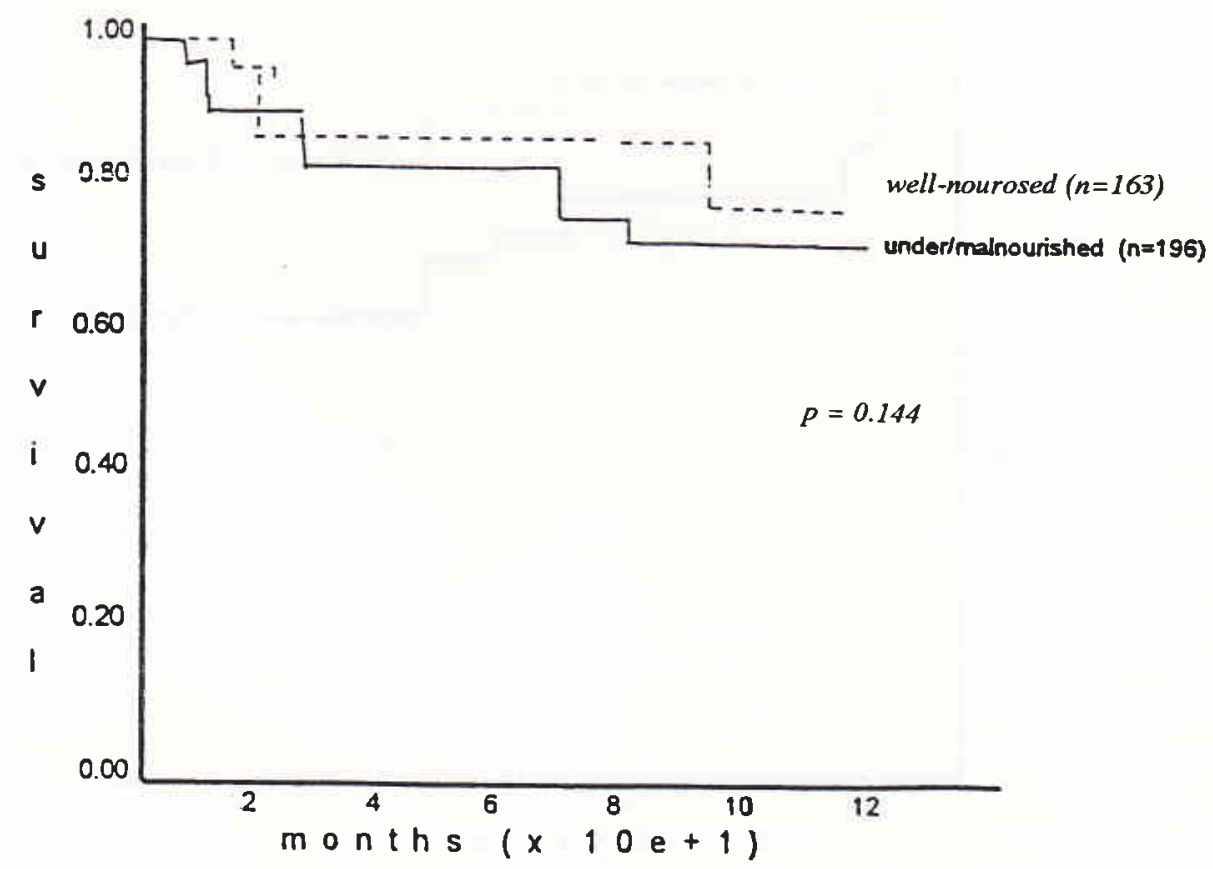

Figure 6. Comparison of survival curves of patients with rheumatic heart disease according to nutritional status 
Table 4. Univariate analyses of factors associated with survival of 177 patients with rheumatic heart disease followed for 5 years

\begin{tabular}{|c|c|c|c|c|c|c|}
\hline & $\begin{array}{l}\text { No of } \\
\text { patients }\end{array}$ & Alive & Dead & $P$ value & Or & $95 \% \mathrm{Cl}$ \\
\hline \multicolumn{7}{|l|}{ Sex } \\
\hline $\begin{array}{l}\text { male } \\
\text { female }\end{array}$ & $\begin{array}{l}85 \\
92\end{array}$ & $\begin{array}{l}71 \\
74\end{array}$ & $\begin{array}{l}14 \\
18\end{array}$ & 0.735 & 1.234 & 0.535 to 2.856 \\
\hline \multicolumn{7}{|l|}{ Age at diagnosis } \\
\hline $\begin{array}{l}<8 \text { years } \\
8 \text { years or more }\end{array}$ & $\begin{array}{r}41 \\
136\end{array}$ & $\begin{array}{r}27 \\
118\end{array}$ & $\begin{array}{l}14 \\
18\end{array}$ & 0.005 & 0.294 & 0.121 to 716 \\
\hline $\begin{array}{l}\text { Valvar involvement } \\
\qquad \begin{array}{l}1 \text { valve } \\
>1 \text { valve }\end{array}\end{array}$ & $\begin{array}{r}112 \\
65\end{array}$ & $\begin{array}{l}97 \\
48\end{array}$ & $\begin{array}{l}10 \\
22\end{array}$ & 0.002 & 3.679 & 1.527 to 9.024 \\
\hline $\begin{array}{l}\text { Parental education } \\
<9 \text { years } \\
9 \text { years or more }\end{array}$ & $\begin{array}{r}101 \\
76\end{array}$ & $\begin{array}{l}82 \\
63\end{array}$ & $\begin{array}{l}19 \\
13\end{array}$ & 0.875 & 0.869 & 0.371 to 2.020 \\
\hline $\begin{array}{l}\text { Nutritional status } \\
\text { well-nourished } \\
\text { undernutrition } \\
\text { malnutrition }\end{array}$ & $\begin{array}{l}81 \\
59 \\
37\end{array}$ & $\begin{array}{l}69 \\
45 \\
31\end{array}$ & $\begin{array}{r}12 \\
14 \\
6 \\
\end{array}$ & 0.355 & & \\
\hline
\end{tabular}

$\mathrm{OR}=$ Odds Ratio; $\mathrm{Cl}=$ Confidence Intervals

Table 5. Logistic regression of several risk factors for survival

\begin{tabular}{lccccccc}
\hline Variable & $\mathrm{B}$ & $\mathrm{SE}$ & Wald & df & Sig & R & Exp. B \\
\hline Sex & -.7236 & .3441 & 4.2323 & 1 & .6672 & -.1072 & .3612 \\
Valv & -.0209 & .0023 & 32.4257 & 1 & .0287 & -.33409 & .9971 \\
Age & -.0422 & .0211 & 28.3265 & 1 & .0334 & -.3079 & .6759 \\
Educ & -.8399 & .0377 & 6.2981 & 1 & .2367 & -.1102 & .4201 \\
Nutr & -.4212 & .1923 & 7.6690 & 1 & .7132 & .2321 & .3400 \\
\hline
\end{tabular}

Valv = valvular involvement; Educ = parental education; Nutr $=$ nutritional status

aged less than 8 years were definitely fewer than those aged 8 years or older.

The type of individual lesion and the number of valves affected are known to be important factors of the long-term prognosis. Our data also support previous reports. ${ }^{14,15}$ that the most frequently affected valve in rheumatic heart disease is the mitral valve (Table 2). It has been suggested that being the most active valve, the mitral valve is prone to suffer from residual affect of the rheumatic process, which is not affected by the use of antiinflammatory drugs. ${ }^{16,17}$ Mitral regurgitation predominated the overall valvular lesion in our series. This type of lesion usually follows acute rheumatic process, either at the first attack or recurrent attacks. When severe enough, it may cause cardiac failure with pulmonary congestion; however, massive pulmonary edema is rarely encountered. Mitral lesion resembling endocarditis usually consisted of mitral regurgitation and stenosis, with dominant mitral regurgitation. At times the mitral regurgitation may abruptly increase as a result of the rupture of the chorda tendinei and other parts of the valve. Endocarditis is rarely found in isolated severe mitral regurgitation.

Mitral stenosis, either alone or in combination with mitral regurgitation was found in many cases, some of them at a very young age, similar to that reported in the 
literature from developing countries. In contrast, in industrial countries stenosis of the mitral orifice develop fairly slowly, years after the acute attack. The underlying mechanism of this phenomenon is not understood. The development of established organic mitral stenosis may further increase the pulmonary arterial pressure leading to pulmonary hypertension and increase the risk of right heart failure and death. Moderate mitral stenosis may be tolerated well by the patient, but severe mitral stenosis (mitral valve area less than $25 \%$ normal) is usually associated with left atrial hypertension leading to severe pulmonary hypertension. This will eventually result in right cardiac failure.

The next most common valve affected is the aortic valve, i.e.aortic insufficiency. Patients with mild to moderate rheumatic aortic regurgitation usually can tolerate and rarely affects their daily activity. Deterioration usually is caused by rheumatic activity, or endocarditis. Many adolescents with severe aortic regurgitation may be totally asymptomatic and can tolerate well untill the $3 \mathrm{rd}$ or 4 th decade. Nevertheless, more than $50 \%$ patients die within 20 years after diagnosis.

We found only a small number of patients with tricuspid abnormality, and no patients with pulmonic disease. Tricuspid regurgitation is usually caused by right venticular dilatation secondary to pulmonary hypertension. This implies left cardiac involvement, usually a combination of mitral regurgitation and stenosis.

With the availability of echocardiography and Doppler, clinically unrecognizable murmur may be detected. Echocardiography has an important role in the long-term management of patients with rheumatic heart disesase; even a minimal regurgitation can be detected. The degree of aortic or mitral regurgitation can be estimated with certain accuracy by using echoDoppler technique. This method has increased the benefit of periodical assessment of patients with rheumatic heart disease.

Although different valvar lesions may lead to a different cause of death, in general the cause of death in patients with rheumatic heart disease is associated with cardiac failure, endocarditis, or dysrhythmias. We did not have data on recurrence or the development of endocarditis in this series; however endocarditis is known to affect the prognosis of patients with rheumatic heart disease. It is understandable that patients who has more than 1 valvar lesion, usually a combination of mitral and aortic regurgitation, have a higher mortality rate than those with only a single valvular involvement.

The management of patients with chronic rheumatic heart disease must include a consideration of invasive treatment, either in the form of balloon dilatation of the stenotic mitral valve, or by surgical valvotomy. Shortterm results indicate that balloon dilatation give comparable results compared to surgical valvotomy. Obviously, surgical valve replacement is difficult, or even impossible to be performed in the pediatric age group, since the patient is growing and developing.

With regard to survival, in general our data support previous evidence that rheumatic heart disease decrease the life expectancy, and many factors contribute to the overall prognosis of patients with established rheumatic heart disaese. The generally known most important factor for the development of severe valvar abnormalities is inadequate administration of antibiotics (usually long-acting penicillin), in patients with existing valvar damage. This encompliance invites the occurence of new streptococcal pharingitis that may lead to another attack of acute rheumatic fever. ${ }^{18}$ We did not include compliance as a risk factor of death, since it was quite difficult to classify the patients into groups according to their compliance to prophylaxis protocol, since almost all patients did not comply.

The severity of cardiac involvement in our parents was also not considered in this analysis with assumption that mild valvar abnormality is rarely associated with significant other valvar abnormality.

We did not have enough data to validly classify the patients according to the family's sosio-economic level. The difficulties arise when we have to consider family income, since it is notoriously known that estimation of family income is rarely reliable. Furthermore, including mother's or father's occupation into the independent variable with also result in similar situation, since many of our parents did not have a permanent occupation. For those and other reasons we chose to average parental education as a proxy for family's sosio-economic status. Obviously this should have affected our unusual result, i.e. that there was no assosiation between patient's prognosis and sosioeconomic level.

Figures 2 to 6 and Tables 4 and 5 demonstrated that age at the time of diagnosis and the number of valvular involvement were assosiated with survival, but paren- 
tal education, sex, and nutritional status were not. Table 4 also demonstrates that in patiens who had follow-up of 5 years, the case fatality rate was $32 / 177$ $(18.1 \%)$. The facts that significant findings in univariate analyses remained so in logistic regression analysis suggested that such associations were strong.

The major weakness of this study is that we do not know the exact time when the rheumatic heart disease started in most of our patients. This is caused by a typical phenomenon in patients with rheumatic heart disease in most developing countries, i.e., that many of them fail to indicate with certaintly when the first symptoms of acute rheumatic fever occurred. Some authors refers this phenomenon as to silent carditis. We are of the opinion that it will take many years before we could get a better information regarding the beginning of the rheumatic process in all patients, i.e., until everyone has an easy access to health services offering adequate facilities to diagnose acute rheumatic fever.

In conclusion, survival analyses of our patients with chronic rheumatic heart disease show that age at the time of diagnosis and the number of cardiac valve affected determined the prognosis of the patient, while nutritional status, sex, and parental education did not. Further study involving more independent variables is necessary for determining overall factors influencing the prognosis of children with rheumatic heart disease.

\section{Acknowledgment}

The authors wish to thank Mr. Theo Stijnen, Statistician, Department of Epidemiology and Biostatistics, Erasmus University, Rotterdam, for his suggestions in managing the survival data.

\section{REFERENCES}

1. Agarwal BL. Rheumatic heart disease unabated in developing countries. Lancet 1981;ii:910-1.

2. Ayoub EM. Acute rheumatic fever. In: Adams FH, Emmanuillides GC, Riemenschneider TA, editors. Mos' Heart disease in infants, children, and adolescents. 4 th ed. London: Williams \& Wilkins, 1989;692-704.

3. Taranta A, Markowitz M. Rheumatic fever. 2nd ed. Boston: Kluwer Academic Publisher, 1989

4. Sievero J, Hall P. Incidence of acute theumatic fever. $\mathrm{Br}$ Heart J 1971;33:833-6.

5. Majeed HA, Khan N, Dabbagh M, et al. Acute rheumatic fever during childhood in Kuwait: the mild nature the initial attack. Ann Trop Paediatr 1981;1:13-20.
6. Veasy LG, Wiedmeier SE, Orsmond GS, et al. Resurgence of acute rheumatic fever in the intermountain area of the United States. N Engl J Med 1987;316:421-7.

7. Markowitz M. The decline of rheumatic fever: role of medical intervention. Pediatrics 1966;106:545-50.

8. Committee on Rheumatic Fever and Infective Endocarditis of the Council on Cardiovascular Disease in the Young, America Heart Association. Prevention of rheumatic fever. Circulation 1985;70:1118A-1122A.

9. Barlow JB, Pocock WA. The problems of nonejection systolic clicks and associated mitral systolic murmurs: emphasis on the billowing mitral leaflet syndrome. Am Heart J 1975;90:636-9

10. Wahab AS. Penyakit jantung reumatik. In: Sastroasmoro $S$, Madiyono B, editors. Buku ajar kardiologi anak. Jakarta: Ikatan Dokter Anak Indonesia, 1994.

11. Helmcke F, Nanda NC, Hsiung MC, et al. Color Doppler assessment of mitral regurgitation with orthogonal planes. Circulation 1987;75:175-83.

12. Putra ST, Sastroasmoro S, Madiyono B, Oesman IN. Echocardiographic diagnosis of acute rheumatic fever in children. Paediatr Indones 1993;33:227-31.

13. Madiyono B. Diagnosis of rheumatic fever and rheumatic heart disease: which modification? Paediatr Indones 1994;34:78-87.

14. Hudson REB. Cardiovascular pathology vol. 3. Baltimore: Williams \& Wilkins, 1970;549-81.

15. Markowitz M, Gordis L. Rheumatic fever. Pliladelphia: Saunders, 1972.

16. Combined Rheumatic Fever Study Group. A comparison of the effect of prednisone and acetylsalicylic acid on the incidence of residual rheumatic heart disease. $N$ Engl J Med 1960;262:895-902.

17. Combined Rheumatic Fever Study Group. A comparison of short-term, intensive prednisone and acetysalicylic acid therapy in the treatment of acute rheumatic fever. N Engl J Med 1965;272:63-70.

18. Sastroasmoro S, Madiyono B, Oesman IN, Putra ST. Bacterial endocarditis in children: Clinical and laboratory findings, and the role of echocardiography in its diagnosis and treatment. Paediatr Indones 1989;29:188-98.

19. Gordis L. Changing risk of rheumatic fever. In: Shulman $S$, Editor. Management of pharyngitis in an era of declining rheumatic fever: The 86th Ross Conference on Pediatric Research. Colombus, Ross Laboratories, 1983, pp 7-13.

20. Tompkins DG, Boxebaum B, Liebman J. Long-term prognosis of rheumatic fever patients receiving regular intramuscular benzathine penicilin. Circulation 1972;45:543-51.

21. Gotsman MS, van der Horst RL. Surgical management of severe mitral valve disease in childhold. Am Heart $J$ 1975;90:685-92.

22. Rachman OJ. Kardiologi intervensional. In: Sastroasmoro S, Madiyono B, editors. Buku ajar kardiologi anak. Jakarta: Ikatan Dokter Anak Indonesia, 1994. 